Cornell Law Library

Scholarship@Cornell Law: A Digital Repository

Cornell Law Faculty Publications

Faculty Scholarship

$10-1-1982$

\title{
Methodological Issues in the Evaluation of "Experiments" with Cameras in the Courts
}

Dan Slater

Valerie P. Hans

Cornell Law School, valerie.hans@cornell.edu

Follow this and additional works at: http://scholarship.law.cornell.edu/facpub

Part of the Courts Commons, and the Law and Society Commons

\section{Recommended Citation}

Slater, Dan and Hans, Valerie P., "Methodological Issues in the Evaluation of "Experiments" with Cameras in the Courts" (1982). Cornell Law Faculty Publications. Paper 420.

http://scholarship.law.cornell.edu/facpub/420

This Article is brought to you for free and open access by the Faculty Scholarship at Scholarship@Cornell Law: A Digital Repository. It has been accepted for inclusion in Cornell Law Faculty Publications by an authorized administrator of Scholarship@Cornell Law: A Digital Repository. For more information, please contact jmp8@cornell.edu. 


\title{
METHODOLOGICAL ISSUES IN THE EVALUATION OF "EXPERIMENTS" WITH CAMERAS IN THE COURTS
}

\author{
DAN SLATER \\ VALERIE P. HANS
}

\begin{abstract}
Evaluations of "experiments" of extended media coverage of the courts, i.e., cameras in the courts, have relied upon survey research. The authors argue that such evaluations have been inadequate and future evalutions need to compare conventional media coverage vs. extended media coverage using field experimental research designs.
\end{abstract}

Dan Slater (Ph.D., University of Oregon) is Assistant Professor in the Department of Communication and Valerie P. Hans (Ph.D., University of Toronto) is Assistant Professor in the Division of Criminal Justice and Department of Psychology, both at the University of Delaware, Newark, Delaware 19711.

In the wake of the decision of the United States Supreme Court in Chandler et al. v. Florida (1981), an increasing number of states are moving rapidly toward opening their courtrooms to coverage by broadcast media and still photographers (see discussions by American Bar Association, 1979; D'Alemberte, 1980; Davis, 1980; Gerbner, 1980; Hirschhorn, 1980; Hughes, 1982; Kielbowicz, 1979; Meeske, 1981; Netteburg, 1980; Platte, 1981; Siegel, 1980; "Symposium," 1981). With encouragement from news media representatives, many states have launched "experiments," a test period usually for one year, during which time "extended media coverage," 1 i.e., cameras in the courts, is permitted, monitored, and evaluated. The purpose of this article is to discuss methodological issues in the evaluation of these "experiments." It is our contention that the research conducted so far, even in the aggregate, provides a qualitatively inadequate collection of evidence on which to base permanent rulemaking.

One state which recently has wrestled with the issue of cameras in the courts is Delaware. In 1978 the Chief Justice of the Delaware Supreme Court, Daniel L. Herrmann, asked the Bar-Bench-Press Conference of Delaware, a group of lawyers, judges, and news media representatives, to study the issue and provide recommendations concerning extended media coverage of the Delaware courts. On April 22, 1980, Chief Justice Herrmann requested that any final report be delayed pending the U.S. Supreme Court's decision in the Chandler case. During this period the Bar-Bench-Press Conference received the results of a study it commissioned which surveyed attitudes toward extended media coverage among judges, attorneys, and news media representatives in Delaware. This study concluded that there was "considerable support for a television experiment, particularly among the judges and media representatives" (Wenger, 1981, p. 66 ) in the sample. However, a majority of attorneys surveyed was opposed to any changes in rules governing cameras in the Delaware courts.

On January 26, 1981, the U.S. Supreme Court issued its decision in the Chandler case. In the majority opinion, Chief Justice Warren Burger wrote:

at present no one has been able to present empirical data sufficient to establish that the mere presence of the broadcast media inherently has an adverse effect on [the judicial] process (Chandler et al. v. Florida, p. 17)

That conclusion rests on the findings of a fairly limited body of survey research, the typical method of investigation used in the evaluations of extended media coverage "experiments."

Subsequent to the Chandler decision, the BarBench-Press Conference, on March 16, 1981, submitted its report to the Delaware Supreme Court. The Conference advocated a suspension of current rules to permit a one year "experiment" (Report of the Bar-Bench-Press Conference, 1981). The Conference, however, did not address the issue of how that test period should be evaluated. On September 24, 1981, the Delaware Supreme Court held a hearing to gather public opinion regarding the Conference's report and recommendations. We reviewed the report and testified at the hearing (Cohen, 1981). 
In preparing our testimony we discovered that a significant problem exists in how evaluations of these "experiments" are conducted by the states. Indeed, it is unfortunate that these initial test periods have been called "experiments" as that label masks the type of evaluative procedures used. The evaluations have not included experimental designs but rather have employed other evaluative procedures such as post-hoc interviews and questionnaire studies involving participants in trials with extended media coverage. In line with the Bar-Bench-Press Conference recommendation, we also advocated a test period for extended media coverage in Delaware. But, additionally, we argued that a true scientific experiment should be the primary procedure used to evaluate the effects of extended media coverage during the test period.

On January 15, 1982, the Delaware Supreme Court issued its Order that current rules be suspended for a period of one year to permit an "experiment" of extended media coverage, but for appellate proceedings in the Delaware Supreme Court only (Supreme Court of the State of Delaware, 1982a). Their rationale for limiting the test to the appellate level was based on their belief that extended media coverage at the trial court level might present two possible threats:

(a) possible adverse psychological impact upon the public and upon participants in the trial, especially jurors and witnesses; and (b) possible prejudicial publicity and violation of rights of privacy of participants in the trial, especially of jurors and witnesses. (1982a, p. 3)

The Delaware Supreme Court noted in reference to these potential dangers the lack of comprehensive empirical data and that available data were limited and nonexperimental. Indeed, they argue that an experiment "in the scientifically adequate and acceptable sense of the word - including scientific controls and scientific evaluation which meet advanced testing techniques and requirements of the social sciences" (1982a, pp. 3-4) is the type of research on which "an informed policy judgment" (1982a, p. 4) should be based. However, citing the aforementioned potential adverse effects and the cost of undertaking an evaluation involving a true experimental study, the Justices decided to limit the one year test to appellate proceedings in the state Supreme Court. Following the issuance of this Order, the Supreme Court asked the BarBench-Press Conference of Delaware to develop a set of guidelines for the one year test period. On April 29, 1982, the Delaware Supreme Court adopted these rules (Supreme Court of the State of Delaware, 1982b). While the guidelines adequately specify the acceptable equipment and usage of equipment by media personnel, their glaring omission is the failure to provide mechanisms for evaluating the effects of extended media coverage. The test year commenced on May 1, 1982, with no formal evaluation in place.

While the Delaware Supreme Court's concern with potential adverse effects of extended media coverage at the trial level is understandable, without a true scientifically-evaluated experiment, it is difficult to determine whether such adverse effects exist and the dangers cited are real. The Court, in fact, recognized this in their initial Order which limited the one year test to the appellate level. Conducting an "experiment" only at the appellate level provides very little information about how extended media coverage will affect trial proceedings since at the appellate level there are no witnesses and no jurors. These two groups are the object of most concern in writings about the negative effects of cameras in the courts. Further, as evidenced by experiences in California, the media are primarily interested in covering trials, not appellate proceedings (Short, 1981). Thus, the decision of the Delaware Supreme Court in this matter simply reinforces the need for experiments at the trial level with evaluative procedures that will provide more definitive answers and information on which courts can rely.

In spite of the inadequacy of evaluative procedures used to date, at least fourteen states already have approved, on a permanent basis, extended media coverage at both the trial and appellate levels, five have approved such coverage only at the appellate level, and one state allows extended media coverage only in nonjury civil trials. Another dozen states have engaged in, or currently are in the midst of, their "experiments" while another half dozen are considering initiating such a test period (Abrahams, 1981; Carter, 1981; "Cameras in the Courtroom: State-by-State Summary," 1981). Supporters and opponents of extended media coverage of the courts have agreed on one point: there is a pressing need to evaluate these "experiments" with cameras in the courts using experimental designs rather than continuing the type of research which has been conducted in the past (Davis, 1980; Gerbner, 1980; Meeske, 1981; Netteburg, 1980).

We bring the issue of the proper method of evaluation of extended media coverage "experiments" to the fore to underline the necessity and timeliness of conducting evaluations using true experimental research procedures.

\section{Survey vs. Experimental Research}

The primary method of evaluating the results of "experiments" of extended media coverage has been through the use of survey research instruments. For example, the much publicized Florida evaluation used attitude surveys of trial participants 
as the major evaluative device (Craig, 1979; Hughes, 1982; Judicial Coordination Planning Unit, 1978).

The most recent study of a state's "experiment" occurred in California. In 1980 the Judicial Council of California authorized a one year "experiment" (Blake, 1980) and the resulting test period was evaluated by an independent research firm using extensive surveys combined with data gathered from interviews and trained courtroom observers (Short, 1981). This research study was extensive in nature and professionally executed. It is the single most comprehensive extended media coverage study to date. In addition to the survey instruments, the researchers attempted to "isolate" the effect of extended media coverage over and above conventional media coverage of trials. This is the critical issue: what effect does coverage with in-court cameras have on judicial proceedings and trial participants beyond conventional media coverage? In the California study, "baseline" and "experimental" data were collected from approximately 35 trials, about half of which had extended coverage and half only conventional coverage. The researchers concluded:

Taken globally, there is little evidence in this evaluation to suggest that [extended media coverage] causes significantly more changes in behavior [of trial participants] than does conventional coverage. (Short, 1981, p. 228).

While such an effort to analyze data scientifically is important, the way in which the data were gathered for this analysis reduced the validity. The "baseline" or conventional-only data were gathered from (1) trials with conventional-only coverage; (2) trials in which cameras were present only intermittently, that is, the coverage was "baseline" when cameras were not present but then shifted to "experimental" during the same trial when cameras were present; and (3) trials which were subsequently retried with cameras present (or viceversa). The difficulty with this procedure, in the case of the second collection method and to a lesser extent the third, is that it is impossible to control for contamination, rendering the results less dependable. The California evaluation clearly is superior to research conducted to date as it adds to the survey research extensive interview and incourt observational evaluations. The experimentaltype research on conventional vs. extended media coverage is important, but the data are subject to problems of internal validity. The California study, which was conducted under the research constraints imposed by the Judicial Council of California, thus is not a true experiment. Its contribution to our knowledge on the subject of extended media coverage from the perspectives of survey and observational research, however, is great.
Survey research, as in the above examples, provides information on people's attitudes toward, and perceptions of, the phenomenon being investigated (see Simon, 1969, pp. 228-255). Although the data collected through such surveys are important, such instruments alone are incapable of controlling for, or isolating, the influence of a particular variable, in this case extended media coverage. In survey research there is no effort to manipulate the key variable. In experimental research, on the other hand, the investigator can systematically manipulate or alter an element of reality and then analyze the results that follow. Experimental studies may be naturalistic, laboratory, or field. Unfortunately, on the cameras in the courts topic, studies employing any of these experimental methods are rare.

In the naturalistic experiment the researcher can investigate a situation which has occurred naturally in the environment without going to the trouble of creating that reality experimentally. In the laboratory experiment, the researcher attempts to study the experimental variable by creating an approximation of real life, or one aspect of real life. Two lab studies are often cited in relation to the cameras in the courts issue. Both are partially applicable. The first is often mentioned as showing experimental evidence that the presence of cameras does not interfere with the ability of individuals to recall information (Hoyt, 1977). The researcher's purpose was to approximate conditions witnesses may find in trials with extended media coverage. Subjects - twelve in each of three conditions - were asked to recall information concerning a film they had reviewed about German post offices either in the presence of an unobtrusive camera, an obtrusive camera, or no camera. No differences were found on a number of dimensions. While an important attempt to approximate an element of a courtroom situation in an experimental setting, this study must be viewed only as exploratory. The number of subjects was limited. More importantly, though, is that the influence of extended media coverage must be studied in comparison to the influence of conventional media coverage. The "no camera" (conventional) condition in this study did not adequately approximate the reality of a trial which is covered by conventional means.

The second laboratory study involved a series of experiments to investigate the impact of the use of videotaped testimony. In this research by Miller and Fontes (1979) the issue under study was jurors' reactions to videotaped vs. live testimony, not the effects of extended media coverage on courtroom participants, the public, or the legal system. This research, therefore, is only partially germane. Its focus is on the use of videotape technology for internal court purposes, not dissemination of information about a trial by the news media. 
However, as an example of experimental research with good external validity, it might be used as a model for laboratory investigation of extended media coverage.

The final type of study is the field experiment. Here the researcher observes real life conditions, but in addition makes a "deliberate manipulation of one or more variables" (Runkel and McGrath, 1972 , p. 94). It is this latter type of experimental research which we believe is essential for proper evaluation of extended media coverage "experiments."

\section{An Outline for Research}

In our testimony before the Delaware Supreme Court, we proposed a design which we believe would have been appropriate to evaluate an experiment of extended media coverage in Delaware, and which could be adapted for use by researchers in other states. The general outline of the systematic evaluation we proposed included attitude surveys, courtroom observers, and other methods used in other states. Beyond this, however, we proposed an outline for a true scientific study - a field experiment - involving the random assignment of extended media coverage to trials. Comparing trials in which coverage is requested and granted with trials which do not generate media interest clearly is insufficient. Comparisons must be made among that subset of trials for which requests for extended media coverage are made. Those trials must then be randomly assigned to "extended coverage" and "conventional coverage" groups.

Thus our proposal involves the following procedure: once the electronic media have expressed an interest in covering a specific trial, and the judge or other authority has declared that extended coverage would be permitted, that specific trial is randomly assigned to either the "extended coverage" or "conventional coverage" group. Trials with extended media coverage can then be compared to trials for which extended media coverage was requested, approved by the judge, but then for the purposes of the research, denied. Because the process of assignment within this subset of trials would be a random one, with a reasonable number of trials ${ }^{2}$ any conclusions that differences between these trials were due to the coverage itself and not to other factors, or that no differences exist, can be supported. Without such controls, conclusions drawn either way may be erroneous. This type of research design, a "posttest-only control group design," assumes that the experimental and control groups (extended coverage and conventional coverage groups) are equal before the introduction of the experimental treatment. This assurance is achieved through randomization (Campbell and Stanley, 1963, p. 25).
In the true experiment, a clear causal inference can be made. An additional research strategy, although one with more threats to internal validity (Lempert, 1966), would be the systematic comparison of trials in states which currently have different rules governing extended media coverage of the courts. For example, comparisons of the attitudes, perceptions, and discomfort levels of trial participants in states with and without extended media coverage can be made. This research strategy takes advantage of the fact that we do have in the U.S. today something akin to a "natural" experiment with cameras in the courts.

Finally, the value of well-designed and realistic laboratory studies should be acknowledged. Conducting experiments in a laboratory setting eliminates the potential for doing harm to the rights of defendants, jurors, and witnesses, the major concern expressed by the Delaware Supreme Court in its decision (Supreme Court of the State of Delaware, 1982a). It is clear that many of the issues in the cameras in the courts debate are amenable to laboratory investigation and that laboratory simulation is a viable method in studying the courtroom situation (Bray and Kerr, 1979, 1982). Using a simulated trial paradigm, one might investigate the impact of being photographed, audio taped, or videotaped on witnesses' memory, physiological stress, self-consciousness, and responses to leading questions. Among simulated jurors, such items as attentiveness, restiveness, degree of discussion and length of deliberation can be researched. In addition to exploring the impact of cameras on trial participants, research also might examine its influence on the public's views of the trial and the verdict. Television serves as the public's primary source of news and far outranks other news media in terms of "believability" (Roper, 1981). If excerpts from trials are included on the evening newscast, will that change the public perception of the trial's credibility and correctness of the verdict? Laboratory studies in this area, comparing reactions to trials presented in different media, could make an important contribution to our understanding of this phenomenon.

\section{Conclusion}

It is critical, in our view, that states support sufficiently complex evaluations which involve survey, observational, and experimental research. This multi-method approach is crucial as not only must the external validity of any experimental findings be established, but also to insure that a complete set of data on the trials and trial participants is gathered. The experimental research component, to date overlooked, should be the centerpiece of future research on extended media coverage of the courts. 
Experimental studies, such as the one proposed here, may find that adverse effects exist. However, they may also "clear" the media of any suspected negative influence by more precisely measuring whether differences among similar trials exist. Without such experimental studies, the influence of extended media coverage on the conduct of trials, the behavior of trial participants, and the judicial process cannot be isolated.

It is also important that such research efforts take place in a number of states. No one study, whether survey or experimental, can form the basis for an important policy decision. Armed with numerous experimental studies, and the data already collected from previous survey research, judges and policy makers can base their decisions about the future of extended media coverage of the courts on a more complete set of empiricallyderived evidence.

\section{NOTES}

1The State of California Rule $980.2(c)(3)$ defines "extended media coverage" as "any media recording or broadcasting of proceedings by the use of television, radio, photographic, or recording equipment." See Short (1981 Appendix A). "Conventional media coverage" refers to traditional methods of covering courtroom proceedings, i.e., coverage by news reporters without benefit of still photographic, electronic videotape, audiotape recorders or other equipment in the courtroom.

${ }^{2}$ The number of trials necessary for adequate experimental power (the ability of an experiment to detect true differences between conditions) depends on the variability of the data. The higher the variability, the more trials one must observe. With an estimate of the variance obtained from a pilot study or from prior work, the researcher may consult a power table (e.g. Winer, 1971 Appendix C, Table C.11) to determine the appropriate sample size.

\section{REFERENCES}

Abrahams, S. New efforts in 17 states to expand cameras coverage of courts. Judicature, 1981, 65, 116-118.

American Bar Association. Cameras in the courtroom: A presidential showcase program. Chicago: American Bar Association, 1979.

Blake, G. Experiment in televising of trials approved for year. Los Angeles Times, March 16, 1980, pp. A3; A32.

Bray, R. M. and Kerr, N. L. Use of the simulation method in the study of jury behavior: Some methodological considerations. Law and Human Behavior, 1979, 3, 107-119.

Bray, R. M. and Kerr, N. L. Methodological considerations in the study of the psychology of the courtroom. In N. L. Kerr and R. M. Bray (Eds.), The psychology of the courtroom. New York: Academic Press, 1982.

Cameras in the courtroom: State-by-state summary of court rules or statutes allowing broadcast coverage of court proceedings. The News Media and the Law, 1981, 5, 64 .
Campbell, D. T. and Stanley, J. C. Experimental and quasi-experimental designs for research. Chicago: Rand McNally \& Company, 1963.

Carter, C. States permitting television, still photography and audio recording coverage of judicial proceedings. Williamsburg, Virginia: National Center for State Courts, 1981.

Chandler et al. v. Florida, slip opinion of the U.S. Supreme Court, No. $79-$ 1260, January 26, 1981.

Cohen, C. 3 back camera use in Delaware courtrooms. (Wilmington, Delaware) Morning News, September 25, 1981, p. C8.

Craig, R. S. Cameras in the courtrooms in Florida. Journalism Quarterly, $1979,56,703-710$.

D'Alemberte, T. Cameras in the courtroom/Yes. Barrister, 1980, 7, 6; 8; 38-39.

Davis, N. Television in our courts: The proven advantages, the unproven dangers, Judicature, 1980, 64, 85-82.

Gerbner, G. Trial by television: Are we at the point of no return? Judicature, $1980,63,416-426$

Hirschhom, J. Cameras in the courtroom/No. Barrister, 1980, 7, 7; 9; 56

Hoyt, J. L. Courtroom coverage: The effects of being televised. Journal of Broadcasting, 1977, 21, 487-495.

Hughes, R. L. Chandler v. Florida: Cameras get probation in courtrooms. Journal of Broadcasting, 1982, 26, 431-444.

Judicial Planning Coordination Unit, Office of State Courts Administrator, State of Florida. A Sample Survey of the Attitudes of Individuals' Associated with Trials Involving Electronic Media and Still Photography Coverage in Selected Florida Courts Between July 5, 1977 and June 30, 1978.

Kielbowicz, R. B. The story behind the adoption of the ban on courtroom cameras. Judicature, $1979,63,14-23$

Lempert, R. Strategies of research design in the legal impact study: The Control of plausible rival hypotheses. Law and Society Review, 1966, 1, 111-132.

Meeske, M. D. Cameras in the courts: What the research says. Paper presented at the Annual Convention of the Speech Communication Association, Anaheim, November 1981.

Miller, G. R. \& Fontes, N. E, Videotape on trial: $A$ view from the jury box. Beverly Hills: Sage Publications, 1979.

Netteburg, K. Does research support the Estes ban on cameras in our courts? Judicature, $1980,63,467-475$.

Platte, M. K. TV in the courtroom: Right of access? Communications and the Law, 1981, 3, 11-29.

Report of the Bar-Bench-Press Conference of Delaware on Television in the Courtroom, March 16, 1981.

Roper Organization, Inc. Evolving public attitudes toward television and other mass media, 1959-1980. New York: Television Information Office, 1981.

Runkel, R. J. and McGrath, J. E. Research on human behavior. New York: Holt, Rinehart and Winston, Inc., 1972.

Short, E. H. Evaluation of California's experiment with extended media coverage of the courts. Sacramento: Ernest H. Short \& Associates, Inc., 1981.

Siegel, B. TV on trial: How does it affect courts? Los Angeles Times, June 15,1980 , p. A1; A7-A10.

Simon, J. L. Basic research methods in social science. New York: Random House, 1969.

Supreme Court of the State of Delaware. Order, In Re 3A(7) of the Delaware Judges' Code of Judicial Conduct, January 15, 1982(a).

Supreme Court of the State of Delaware. Order, In Re $3 A(7)$ of the Delaware Judges' Code of Judicial Conduct, April 29, 1982(b).

Symposium: Television in the courtroom: Limited benefits vital risks? Communications and the Law, 1981, 3, 35-50.

Wenger, D. Television, radio, and photographic coverage of court proceed ings: A survey of Delaware lawyers, judges, and media representatives. Newark, Delaware: University of Delaware Department of Sociology, 1981.

Winer, B. J. Statistical principles in experimental design (2nd Ed.). New York: McGraw-Hill, 1971. 
Copyright of Communication Quarterly is the property of Eastern Communication Association and its content may not be copied or emailed to multiple sites or posted to a listserv without the copyright holder's express written permission. However, users may print, download, or email articles for individual use. 